\title{
Dietary Effect On Cardio-Renal Parameters Of Women Residents In Gas Flares Polluted Environment In Bayelsa State, Nigeria
}

\author{
${ }^{1}$ SOLOMON M UVOH, ${ }^{2}$ KIRIDI EMILY ENIEFA GABRIEL, ${ }^{3}$ TONKIRI AYAKEME, ${ }^{1}$ CHARLES \\ NGAIKEDI NNAMDI ${ }^{1}$ OKUROEMI O HENRIETTA.
}

\begin{abstract}
${ }^{1}$ Department of Human Physiology, Faculty of Basic Medical Sciences, College of Health Sciences University of port Harcourt, Rivers State Nigeria.

${ }^{2}$ Department of Human Physiology, Faculty of Basic Medical Sciences, College of Health Sciences, Niger Delta University Wilberforce island Amossoma, Bayelsa state Nigeria.

${ }^{3}$ Department of Biochemistry, University of Port Harcourt, River state Nigeria.
\end{abstract}

\author{
Corresponding Author: DR SOLOMON M UVOH \\ Email Address; Solomonu31@gmail.com \\ DOI: 10.29322/IJSRP.11.12.2021.p12023 \\ http://dx.doi.org/10.29322/IJSRP.11.12.2021.p12023
}

\begin{abstract}
This study determines the relationship between regular nutritional diet and cardio-renal indices of pregnant and nonpregnant women depending on farm produce, aquatic and animals in gas flaring polluted environment. The body mass index was significantly higher among non-pregnant women regularly engaging in carbohydrate diets $\left(26.21 \mathrm{~kg} / \mathrm{m}^{2}\right)$ compared with protein $\left(25.27 \mathrm{~kg} / \mathrm{m}^{2}\right)$.There was no significant difference in the blood pressure but the pulse pressure was lower among participant regularly indulging in carbohydrates $(43.17 \mathrm{bpm})$ intake in relation to protein (46.18bpm).However, regular protein/carbohydrate intake among pregnant subject indicate an increase weight $(80 \mathrm{~kg})$ and body mass index $\left(30.86 \mathrm{~kg} / \mathrm{m}^{2}\right)$ including blood pressures with a significant $\mathrm{p}$ values compared with subjects centered on carbohydrates mainly and a lower pulse pressure $(43.67 \mathrm{mmhg})$.Furthermore, the renal indices of both pregnant and non-pregnant women group were all significantly higher among participants engaging in regular intake of carbohydrate/protein foods compared with carbohydrate and significant $p$ value $(<0.05)$.. The study result further indicates significant increase in lead value $(0.05 \mathrm{ppm})$ among pregnant women regularly indulging in carbohydrate diet in relation to carbohydrate /protein $(0.045 \mathrm{ppm})$. However increase blood cadmium was observed among pregnant women engaging in regular protein diets in gas flares polluted environment. Regular intake of protein diet without moderation and advice from nutritionist and toxicologist particularly in gas flares polluted environments can lead to renal dysfunction among women.
\end{abstract}

Keywords: protein, carbohydrate, body mass index, weight, height, renal

\section{INTRODUCTION}

Nutritional dietary intake plays a key role in the maintenance of health and prevention of chronic kidney disease though the nutritional recommendation for subjects with chronic kidney disease have been given more attention and the limiting of protein intake but the relevant of diet quality cannot be overlooked (Mohammed et al., 2016). Consumption of certain dietary food grown in soil contaminant by gas flares, tobacco and cigarette communities as combining factors are associated to the development of kidney, lung and bone disorder commonly referred to as Itai-Itai disease in women mainly with severe pain in the joints and spine (Kobayashi et al., 2006 ; Ezaki et al., 2003). The flaring of gases has an adverse effect on crops development such as manihot esculenta, plantains, vegetables and plants within polluted environment in the Niger delta region (Dung et al., 2008).Gas flares give rise to the contamination of both rain water and soil accommodating farm products required for human consumption. 
Consumption rate of proteinous diets in place of carbohydrate though increase the rate of glomerular filtration with associated long term kidney disease progression (Stephen et al., 2018.,).Recent studies have shown an increasing trend of high protein intake in diet due to weight loss which may promote renal damage by increasing the glomerular pressure and hyper filtration (Williams et al., 2005). Food sources rich in carbohydrate are associated with decrease rate of cardiovascular diseases regardless of the content from cassava in the Niger delta region of Nigeria Africa due to the fact that diet rich in carbohydrate are low in fat and protect against overweight and obesity as they act as protective markers (Jim, 2007).However, partial substituted diet of carbohydrate with proteins can thus reduce the risk of cardiovascular risk(Lawrence, 2005).Some sources of carbohydrate in the polluted environment the residents depend upon regularly are found in both healthy and unhealthy foods like bread, nuts, corn, milk, melon, drinks, spaghetti, cassava fibres while protein sources include sea fish, bush meat, nut seeds, beans, peas, guava etc. Study conducted by Enetimi et al (2017) within the Niger Delta region of Nigeria shows the adverse effect of gas flares on the components of the environment such as the soil, air, water and especially vegetation's, animals, fishes with humans being the mostly affected being a dependent on these for survival and may likely experience normal renal Physiological alterations.

Dugdale (1970) defines nutrient requirement as the amount of nutrients considered adequate to meet the physiological needs of the citizens in any country while nutritional status is the state of health an individual determined by the food he eats and a crucial role in the maintenance of hormones, drug reactions, body composition, cell immunological and growth of organs. According to study conducted by Stephen et al 2015 on the effect of carbohydrate on renal function indicate that reduction in dietary carbohydrate favors glomerular filtration rate which in turn reduce urea, creatinine and uric acid level within the serum blood and increase renal function indices. The identification and modification of risk factors associated with renal and cardiovascular diseases is of utmost importance to the preventive measures to reduce the morbidity and mortality rate from dietary intake. Carbohydrate supply energy to the body usually measured in calories that are turn into glucose and with the help of insulin cells they are used for energy to carry out daily task. However, food rich in carbohydrate also provide minerals, fibres and vitamins that protect the body (Davita, 2021). The recommendation of low protein diet to patients with pre dialysis might delay its progression and assist in managing overweight and dyslipidemia (Bruna et al., 2018).Epidemiological studies indicate that subjects with kidney functions below the optimal level of protein intake is linearly related to the incidence of the declination kidney function over time. Therefore, high protein intake can be unhealthy habit in subjects with kidney disease even in the early stage (Giancarlo et al., 2019).

\section{MATERIALS AND METHODS}

\section{Study Design.}

This was a randomly conducted study with semi structured questionnaires to obtain data's directly from pregnant and nonpregnant women in hospitals and health Centre's located in their respective communities.

Study Location. Nembe, Immiringi, Obunagha, Polaku, Tombia and Amossoma. 


\section{Study Population}

Two hundred pregnant and non-pregnant women from different gas flaring environment. The population was reached at the communities health centers with an official permission granted by the in charge. During the interviews the questionnaires were filled.

\section{Methods of data collection}

\section{Weight and height determination}

The weight and height of the voluntary subjects were measured using Youngkang Zhezhong weight and height scale balance while the height was obtained using a calibrated height meter rule. The subjects were all ask to remove shoes and any objects before taking their weight and their height was taking as they stand erect on the scale with an adjusted pointer to level hairs in correspondence with the vertex of the head. Body mass index was calculated using the square of the height to divide the weight of the participants.

\section{Blood pressure}

The blood pressure of the participants was measured in a sitting position with an Omron digital blood pressure apparatus from the left arm after about ten minutes rest.

\section{Renal parameters}

The renal parameters were determined using standard laboratory test kits (Randox, United Kingdom and agape Switzerland) for urea-Berthelot method, creatinine-kinetic method and uric acid-enzymatic colorimetric method. Their regular dietary food intake was obtained directly from the participants through interviews and were documented in the space provided in the questionnaires while blood samples were collected via venipuncture into $5 \mathrm{ml}$ syringes and needles for both renal and heavy metal analysis.

The Statistical analysis of the results obtained were done using SPSS version 23.0 Chicago USA.

\section{Determination of blood cadmium and lead level}

Heavy metal analysis was conducted using Varian AA240 Atomic Absorption Spectrophotometry according to the method of APHA 1995 (American Public Health Association) at Springboard research laboratories Awka Anambra State, Nigeria.

Working principle: Atomic absorption spectrometer's working principle was based on the sample being aspirated into the flame and atomized when the AAS's light beam is directed through the flame into the monochromatic, and into the detector that measures the amount of light absorbed by the atomized element in the flame. Since metals have their own characteristic absorption wavelength, a source lamp composed of that element is used, making the method relatively free from spectral or radiation interferences. The amount of energy of the characteristic wavelength absorbed in the flame is proportional to the concentration of the element in the sample.

\section{Preparation of reference solutions}

A series of standard metal solutions in the optimum concentration range were prepared, the reference solutions were also prepared daily by diluting the single stock element solutions with water containing $1.5 \mathrm{~mL}$ concentrated nitric acid per litre. A calibration blank was prepared using all the reagents except for the metal stock solutions.

\section{Sample Digestion (Adrian, 1973)}

1. Measure $1 \mathrm{ml}$ of sample and add $1 \mathrm{ml}$ of nitric acid

2. Mix properly, boiled at $100^{\circ} \mathrm{c}$ for $30 \mathrm{mins}$

3. Make up to $4 \mathrm{ml}$ for analysis 
4. Measure using FS240AA Agilent atomic absorption spectroscopy

5. Solution $1000 \mathrm{mg} / \mathrm{L}$, of stock metal solution was dissolved in a minimum volume of $(1+1) \mathrm{HNO}_{3}$.

Dilute to 1 litre with $1 \%$ (v/v) HCL, appropriate dilution were carried out to produce 2, 4 and $6 \mathrm{ppm}$ working solution

\section{The dilution factor $=4$}

\section{Inclusion criteria}

- Subjects within the ages of 18 to 60 years depending regularly on farm products from gas flaring environment within Bayelsa state.

\section{Exclusion criteria}

- Participants below 18years

\section{Ethical consideration}

The proposed methodology of this study was approved by the ethical committee of University of Port Harcourt River State Nigeria UPH/CEREMAD/REC/MM62/009.

Consent was obtained from each prospective participant before they could participate in the study. They freely decided to participate without being pressured.

\section{RESULTS}

Table 1: Relationship between nutrition in non-pregnant cardiovascular and anthropometric parameters.

\begin{tabular}{|c|c|c|c|}
\hline Parameters & Carbohydrates $(n=154)$ & $\begin{array}{l}\text { Carb/Protein } \\
(n=46)\end{array}$ & $\begin{array}{l}\text { Significant } \\
\mathrm{P}<0.05\end{array}$ \\
\hline Age (yrs.) & $28.82 \pm 5.39$ & $30.87 \pm 6.10$ & 0.69 not significant \\
\hline Height (m) & $1.59 \pm 0.06$ & $1.61 \pm 0.56$ & $0.00 \#$ \\
\hline Weight(m) & $66.87 \pm 12.69$ & $65.21 \pm 11.94$ & $0.03 \#$ \\
\hline BMI $\left(\mathrm{kg} / \mathrm{M}^{2}\right)$ & $26.21 \pm 4.62$ & $25.27 \pm 4.57$ & $0.00 \#$ \\
\hline $\mathrm{SBP}(\mathrm{mmHg})$ & $112.45 \pm 12.81$ & $112.53 \pm 19.45$ & 0.74 not significant \\
\hline DBP (mmHg) & $68.86 \pm 11.41$ & $74.36 \pm 12.57$ & 0.10 not significant \\
\hline
\end{tabular}


NB: Results are given as mean standard deviation. \#=significant

Table2: Nutritional status of pregnant women with cardiovascular and anthropometric parameters.

\begin{tabular}{|c|c|c|c|}
\hline Parameters & Carbohydrates $(\mathrm{N}=140)$ & $\begin{array}{l}\text { Carb/Protein } \\
(\mathrm{N}=60)\end{array}$ & $\begin{array}{l}\text { Significant } \\
\mathrm{P}<0.05\end{array}$ \\
\hline Height(m) & $1.59 \pm 0.06$ & $1.62 \pm 0.05$ & 0.63 not significant \\
\hline Weight (kg) & $67.25 \pm 14.48$ & $80.18 \pm 9.06$ & $0.01 \#$ \\
\hline BMI $\left(\mathrm{kg} / \mathbf{M}^{2}\right)$ & $26.25 \pm 5.27$ & $30.86 \pm 3.60$ & $0.01 \#$ \\
\hline SBP (mmHg) & $114.18 \pm 14.05$ & $115.83 \pm 17.18$ & $0.03 \#$ \\
\hline DBP (mmHg) & $68.56 \pm 11.24$ & $72.28 \pm 14.49$ & 0.04\# \\
\hline MAP (mmHg) & $83.93 \pm 11.32$ & $86.79 \pm 14.89$ & 0.04\# \\
\hline Pulse (bpm) & $84.59 \pm 10.78$ & $85.50 \pm 11.4$ & $0.01 \#$ \\
\hline Pulse pressure (mmHg) & $46.86 \pm 10.14$ & $43.67 \pm 8.79$ & $0.03 \#$ \\
\hline
\end{tabular}

NB: Results are given as mean \pm standard deviation \# significant .

Table3: Relationship between nutrition and renal function in non-pregnant Subjects

\begin{tabular}{llll}
\hline Parameters & $\begin{array}{l}\text { Carbohydrate } \\
(\mathbf{n}=\mathbf{1 5 4})\end{array}$ & $\begin{array}{l}\text { Carb/Pro } \\
(\mathbf{n}=\mathbf{4 6})\end{array}$ & $\begin{array}{l}\text { Significant } \\
\end{array}$ \\
\hline Uric Acid (mg/dl & $3.58 \pm 1.20$ & $4.51 \pm 0.05$ & $0.02 \#$ \\
Urea (mmol/L & $3.11 \pm 0.75$ & $4.48 \pm 0.99$ & $0.00 \#$ \\
& & \\
Creatinine & $85.93 \pm 19.60$ & $99.85 \pm 23.87$ & $0.01 \#$ \\
$(\boldsymbol{\mu m o l} / \mathbf{L})$ & & \\
\hline
\end{tabular}


Table4: Relationship between nutrition and renal function during pregnancy

\begin{tabular}{llll}
\hline Parameters & Carbohydrate & Carb/Protein & significant \\
& $\mathrm{N}=140$ & $\mathrm{~N}=60$ & $\mathrm{P}<0.05$ \\
\hline Uric Acid $(\mathbf{m g} / \mathbf{d L})$ & $3.25 \pm 1.25$ & $5.12 \pm 0.91$ & $0.01 \#$ \\
Urea $(\mathbf{m m o l} / \mathbf{L})$ & $2.36 \pm 0.78$ & $4.27 \pm 1.12$ & $0.00 \#$ \\
Creatinine $(\boldsymbol{\mu m o l} / \mathbf{L})$ & & & \\
\hline
\end{tabular}

Table 5: Relationship between nutrition and heavy metals during pregnancy

\begin{tabular}{|c|c|c|c|}
\hline \multirow[t]{2}{*}{ Parameters } & Carbohydrate & Carboh/Protein & significant \\
\hline & $\mathrm{N}=140$ & $\mathrm{~N}=60$ & $\mathrm{P}<0.05$ \\
\hline
\end{tabular}

$\begin{array}{llll}\mathbf{P b}(\mathbf{p p m}) & 0.05 \pm 0.013 & 0.045 \pm 0.03 & 0.03 \text { significant } \\ \mathbf{C d}(\mathbf{p p m}) & 0.001 \pm 0.0005 & 0.036 \pm 0.02 & 0.04 \text { Significant }\end{array}$

NB: Results are given as mean \pm standard deviation.

\section{DISCUSSION}

\section{Effect of Nutrition on Cardio-renal Parameters}

The kidney plays major role in the filtration and removal of waste products of metabolism from the blood stream through regulatory mechanism of blood volume, acidic and electrolyte concentration (Rayner et al., 2016). Crops planted in gas flaring communities are likely to experience the effect of gas flares and humans who in turn depend on such farm products for survival may also likely suffer the after effect. The study reveal a significant systolic, diastolic and mean arterial blood pressure of pregnant women living in gas flaring communities engaging regularly in Carbohydrate/proteins, as part of their daily diet with a $p$-value of $(0.03,0.04$ and 0.04$)$ respectively. The pulse rate and pulse pressure of this same group were observed $(85 \mathrm{bpm}),(43 \mathrm{mmHg})$ compared with those who centered their diet mostly on carbohydrates $(84 \mathrm{bpm}, 46 \mathrm{mmHg})$. However, in the case of the non-pregnant group the pulse pressure $(46 \mathrm{mmHg})$ of subjects on protein was significantly higher than their pregnant counterpart. The diastolic and mean arterial blood pressures $(74,87 \mathrm{mmHg})$ of the non-pregnant on carbohydrate in addition to proteins diet were also higher than the pregnant group. The pulse rates $(85 \mathrm{bpm})$ of the pregnant group on carbohydrate and 
protein diet were of higher beats than the non-pregnant (84bpm) group. Uvoh et al (2021) observed a significant increase in systolic, diastolic, and mean arterial blood pressure among pregnant women subjects exposed to gas flares from his research study conducted in Bayelsa state. We noticed a significant (0.00) (0.01) increased in serum urea and uric acid level among the pregnant group consuming protein dietary food regularly than carbohydrate $(4.27 \mathrm{mmol} \& 5.12 \mathrm{mg} / \mathrm{dl})$ as against $(2.36 \mathrm{mmol} / \mathrm{l} \& 3.25 \mathrm{mg} / \mathrm{dl})$. An elevated serum uric acid is a key factor leading to the development of articular degeneration, gout, atherosclerosis and vascular inflammation (Jessica et al., 2015). The creatinine level was significantly (0.01) higher among the non-pregnant subjects consuming carbohydrate and protein. There was a similar increase in creatinine level was also observed among the pregnant group with statistical significant $p$ value (0.03). This study is congruent with findings from studies conducted by Solomon et al (2021) among pregnant and non-pregnant women with a positive correlation between urea, uric acid with age and duration of exposure to gas flares in Bayelsa state. Regular consumption of dietary food rich in proteins on a daily basis than other dietary fibres could be a determinant factor to the increase of blood serum urea level among pregnant women subjects (Imoru et al., 2016). The blood cadmium level among the pregnant women engaging regularly on carbohydrates and protein diets was significantly higher $(0.036 \mathrm{ppm})$ compared with regular carbohydrate intake of $(0.001 \mathrm{ppm})$. There is an increasing trend of significant prevalent increase in serum cadmium and lead from $12.33 \%$ to $26.66 \%$ and $5 \%$ to $31.33 \%$ among nonpregnant and pregnant women in Bayelsa state This study has shown that both animals, sea fishes rich in protein source consumed by the residents must have been affected by indiscriminate gas flares components containing these metals which in turn give rise to the blood concentration level among the pregnant women in addition to their exposures (Chibuzor et al.,2016; Nwankwo et al., 2011).

\section{Effect of Nutrition on Anthropometric Data}

The study results showed a decrease in the Weight and Body Mass Index of the non-pregnant group consistently engaging in protein/vegetables/fruits and carbohydrate/proteins food $(65.21 \mathrm{~kg})\left(25.27 \mathrm{~kg} / \mathrm{m}^{2}\right)$. A contrary effect was observed among the pregnant group whose weight $(80.18 \mathrm{~kg})$ and Body mass index $\left.(30.86 \mathrm{~kg}) / \mathrm{m}^{2}\right)$ increase above those engaging in carbohydrate diet $(67.25 \mathrm{~kg})\left(26.25 \mathrm{~kg} / \mathrm{m}^{2}\right)$ regularly.

\section{CONCLUSION}

This study have shown that gas flares in association to their toxic components adversely affect both non-pregnant and pregnant women depending on abiotic and biotic factors in such polluted environment for survival by altering their anthropometric and renal indices. However, higher pulse rate was observed among both groups and reduction in pulse pressure of both participants engaging regularly on carbohydrate compared with carbohydrate/protein diets.

Conflict of interest: There is no conflict of interest between the authors of this article.

\section{REFERENCES}

American Public Health Association (1998).Direct Air- Acetylene Flame Method

Bruna CF,Juliana SA,Ana pb,Nara XM,Denise M (2018).Effect of low protein diet on lipid and anthropometric profile of patients with chronic kidney disease on conservative management.40,(2)

Chibuzor E.B (2016).Gas flaring and rain water composition-A synergy:A case study of utorogu community in Niger Delta, Nigeria. Journal of Environmental Science 3(2):124-30 
Davidta intergrated kidney care and clinical research Inc.2021

Dung EJ, Bombom LS, Agusomu ID (2008).Effect of gas flaring on crops in the Niger

Geo.

Journal,delta,Nigeria 73(4):297-305

Dugdale AE (1970).Nutritional requirement of infants Far East. Journal of medicine 6,8

Enetimi IS and Sylvester CI(2017).A review of impact of gas flaring vegetation and water resources in the Niger Delta region of Nigeria.International Journal of economy energy and environment 2(24):48-55

Giancarlo B,Pierpaol C,Carolina C,Massimo C (2019).Dietary protein,kidney function and mortality:Review of the evidence from epidemiological studies.11(1):10.3390/1101096.

Imoru M and Isah S.Y (2016). Changes in paeked cell volume and some Biochemical parameters of adult females during pregnancy in North West Nigeria. International Blood Research and Reviews 5(2):1-6, IBRR.24544.

Jim M (2007).Dietary carbohydrate relationship to cardiovascular disease and disorders of European journal of nutrition61 (1):5100-5111

carbohydrate metabolism.

Lawrence JA, Frank M, Vincent JC (2005).Effect of protein monosaturatedfat and carbohydrate intake on blood pressure and serum lipids.JAMA 294(19):2455-

2464

Mohammad HR,Mojgan MN,Ahmad E,Awat F,Leila A (2016).Dietary energy density, renal function and progression of chronic kidney disease.Hindawi pub. Corporation advances in medicine 2675345, 7

Nwankwo CN and Ogagarue DO (2011).Effect of gas flaring on surface water and ground water in Delta State.Journal of. Geology and Mining Research 3(5):131-136.

Rayner HC,Mark AB,David VM (2016).Kidney Anatomy and Physiology.Researchgate Doi:10.1007/978-3-319-23458-81

Solomon M Uvoh, Arthur N Chuemere, Obia Onyebuchi (2021).Assessment of consistent exposure to gas flares and renal indices during pregnancy: A baseline study in Bayelsa state Nigeria. International journal of medical and applied sciences vol.10 (2):54-60.

Solomon M Uvoh, Charles Nnamdi Ngaikedi, Kiridi Emily Gabriel E (2021).Blood serum lead and cadmium level among pregnant women in gas flaring communities in Bayelsa state Nigeria. International Journal of scientific and research publications vol.11 (5) p11316.

Stephen PJ, Alex RC, Lawrence JA, Cheryl A.M.A, Deidra CC, et al (2018) Effect of $\quad$ glycaemic index and carbohydrate intake on kidney function in healthy adults. Biomed centralNephrology17:70.

Stephen PJ, Alex RC, Lawrence JA, Cheryl A.A, Deidra CC, et al (2015)The effect of $\quad$ carbohydrate amount and type on kidney function in healthy adults. Results from the omnicarbtrial, 131:A21.

Solomon M Uvoh, Nwafor A Chuemere, Azibalua A Asara (2021).Evaluation of some cardiovascular parameters of apparently healthy pregnant women in gas flaring communities: A baseline study in Bayelsa state Nigeria. Journal of research in medicine and medical sciences vol.2 (6) pp104-108.

Solomon M Uvoh, Asara A Azibalua, Charles Ngaikedi Nnamdi (2021).Effect of contaminated air renal indices of non-pregnant women in Bayelsa state Nigeria International journal of research in biological and medicine sciences vol.04 (09):41-48. 
